English Studies
UNIVERSITY OF MURCIA

\title{
Myth, Form and Intertextuality in Edwin Muir
}

\author{
GABRIEL INSAUSTI* \\ University of Navarre (Spain)
}

Received: 30/03/2021. Accepted: 17/08/2021.

\begin{abstract}
Edwin Muir has often embarrassed critics as a rara avis. He was overlooked by anthologists before 1950 and, although subsequent anthologies never failed to include him, he was still hard to place for many readers. Labelled as a "traditionalist" or a "craftsman", his later work proves however that Muir was much more. Understanding his use of myth, form and intertextuality enables us to rethink the significance of his work in the twentieth-century context.
\end{abstract}

KEYWORDS: Edwin Muir; Form; Myth; Intertextuality; Modernism.

\section{TRADITIONALIST?}

Edwin Muir has often embarrassed critics as a rara avis in the context of modern poetry. He was overlooked by all anthologies before The Penguin Book of Contemporary Verse (Allott, 1950), when he was already sixty-three years old; editors of some of the previous anthologies, such as Michael Roberts in the Faber Book of Modern Verse (1936), even explained that Muir had not made any "notable development of poetic technique" (it was, however, Roberts himself who included Muir in his 1951 Faber Book of Modern Verse). In any case, subsequent anthologies never failed to include Muir: The Faber Book of English Verse (Hayward, 1958); Modern British Poetry (Untermeyer, 1962); Chief Modern Poets of England and America (Sander, Nelson \& Rosenthal, 1962); The Oxford Book of Scottish Verse (MacQueen \& Scott, 1966), Poetry of the 1940s: An Anthology (Sergeant, 1970), etc.

*Address for correspondence: Facultad de Filosofía y Letras, Edificio Bibliotecas, Universidad de Navarra, 31080, Pamplona; e-mail: ginsausti@unav.es 
The difficulty of placing Muir still persisted: he was only posthumously included among Scottish authors; instead, he was sometimes taken for an American or an Englishman. Finally, later collections, like The Oxford Book of Twentieth-Century Verse (Larkin, 1973), plus T. S. Eliot's appraisal in his prologue to a 1965 Faber anthology of Muir's poems would ultimately settle the whole question. In fact, it was precisely during the late sixties and the seventies when critical studies about Muir proliferated, — see, for instance, those by Peter Butter, J. E. Gilmer, J. Brooks Bouson, Elizabeth Huberman and Travis L. Livingston.

Most of these studies took a biographical approach and emphasized the poet's early departure from the Orkney islands and his traumatic life in Glasgow. Besides, they could not help viewing Muir as a figure standing against the background of English modernism. As a result, they almost unanimously took a safe path and labelled him as a "traditionalist". And, by doing this, they neglected perhaps some of his work's most valuable aspects: already in the twenties, when reviewing Muir's First Poems for Poetry, Marie Luhrs certainly read Muir's first poetic attempts as lacking in novelty and underlined its shortcomings, but she also wrote that "mysticism and simplicity are rare qualities in this hour" and that "originality is more valuable than fashionable mannerism" (1925: 51). There was a sense of authenticity about Muir, although the poet was still to find his own voice.

Later remarks about Muir's poetry — and idiosyncrasy — insist on this approach: Kathleen Raine (1964: 233) paved the way in this regard when she wrote that Muir was a poet who "never followed fashion"; Elgin W. Mellown (1964a: 13) thought that Muir's poems "embody the traditional wisdom of civilized man"; Huberman (1971: 100) wrote that Muir's themes are "the traditional themes" but at the same time he had the strength "to handle this traditional material in his own way"; Brian Keble (1973: 634) saw Muir's craft at the service of "permanent" realities, hence his disregard for fashion; Alan Bold (1976: 176) underlined that Muir "favored a traditional approach to poetry"; J. Brooks Bouson (1978: 111) summarized Muir's achievement by saying that he chose to use "traditional verse and a simple language"; Robert B. Shaw (2007: 137) considered that Muir wrote "durable poems" that addressed modern concerns "in a traditional style"; Andrew Frisardi declared that Muir's poetry lacks interest, the main reason being "its traditional, English, and ballad-influenced prosody", which showed in his utter "lack of technical innovativeness"; Harvey Gross and Robert McDowell (1996: 38) included Muir among those poets who, like Hardy, Yeats and Frost, provide fine examples of "traditional style"; finally, Wikipedia says Muir's poetry is "written in plain language and with few stylistic preoccupations" ("Edwin Muir", 2020) and the University of Edinburgh's website adds that Muir's work displays a "modernist fascination with myth, dream, and fable", although written "in traditional meters".

The final conclusion is almost unanimous: Muir was not "very" modern according to progressive standards; some critics look down on him and attribute this to ineptitude, others 
think it is due to a decision that has paid off in time, inasmuch as it has secured him a place in the realm of "permanence", in contrast to infatuation with topicality. I do not wish to dispute this. Nevertheless, there are a few assumptions I would like to analyze in that line of argument: first, the opposition between "tradition" and "novelty", always a delicate matter in modernism and a crucial issue in a poet who was friends with Eliot; secondly, the idea that this closed notion of tradition and this traditional bias produced paralysis and turned Muir into a mere craftsman rather than a poet; and thirdly, the implication that because he clung to ballad form and his native tradition Muir had no links with modernism.

\section{A FEW POEMS}

I think one way to shed some light on these questions is to reread Muir's poems and observe his use of myth and intertextuality and the cohesive relationship between form and meaning therein. This is not the occasion for a full re-appraisal of his poems so I propose a few instances.

The first is "The Return of the Greeks":

The veteran Greeks came home

Sleepwandering from the war.

They saw the galleys come

Blundering over the bar.

Each soldier with his scar

In rags and tatters came home.

Reading the wall of Troy

Ten years without a change

Was such intense employ

(Just out of the arrows' range),

All the world was strange

After ten years of Troy [...]

But everything trite and strange,

The peace, the parceled ground,

The vinerows - never a change!

The past and the present bound

In one oblivious round

Past thinking trite and strange. [Muir, 1984: 125] 
"The Return of the Greeks" is one of several pieces in Muir's poetry that derive from Homer, the list including poems such as "Ballad of Hector in Hades", "Troy", "A Trojan Slave", "The Return of Odysseus", "The Charm", "Telemachus Remembers", and "Too Much": poems in a narrative form that skip the central episode and focus on some marginal detail. It is also, revealingly, the opening piece in The Voyage (1946), and the date points to a theme that became especially prevalent during the Great War and afterwards, in the hands of war poets like Wilfred Owen or Siegfried Sassoon's, in novels such as Rebecca West's The Return of the Soldier (1918), and in films like King Vidor's The Big Parade (1925). Muir's fidelity to the myth just adds universality to this account of some episode. Yet there is one element that should be noted: the epiphora, the repetition of the last word of the first line in each stanza, that comes back on the last line. It is not simply a rhyme, it is a repetition of the whole word, implying the impossibility of this return, and the mixture of sameness and difference it entails, which was part of the drama as exposed by the war poets. Everything stays the same and yet is different, if only because the soldiers that come back home are not, after the experience of war, the same men that departed a few years before. There is a sound and there is an echo. Thus, the meaning is embodied in the whole poem, by means of its form, and this includes an intertextual reference - the resuscitation of some element from tradition - that the poet takes for granted in order to produce that meaning. So Muir is indeed writing within a long-standing tradition but he is also adding something new.

The second example is "The Labyrinth":

Since I emerged that day from the labyrinth,

Dazed with the tall and echoing passages,

The swift recoils, so many I almost feared

I'd meet myself returning at some smooth corner,

Myself or my ghost, for all here was unreal

After the straw ceased rustling and the bull

Lay dead upon the straw and I remained,

Blood-splashed, if dead or alive I could not tell

In the twilight nothingness (I might have been

A spirit seeking his body through the roads

Of intricate Hades) - ever since I came out

To the world, the still fields swift with flowers, the trees

All bright with blossom, the little green hills, the sea,

The sky and all in movement under it,

Shepherds and flocks and birds and the young and old,

(I stared in wonder at the young and the old, 
For in the maze time had not been with me;

I had strayed, it seemed, past sun and season and change,

Past rest and motion, for I could not tell

At last if I moved or stayed; the maze itself

Revolved around me on its hidden axis

And swept me smoothly to its enemy,

The lovely world) - since I came out that day,

There have been times when I have heard my footsteps

Still echoing in the maze... [Muir, 1984: 163-164]

This piece is likewise central to Muir's work, inasmuch as its title is that of the collection it belongs to: The Labyrinth (1949). Unlike "The Return of the Greeks" it is written in the first person singular, which suggests an existential approach rather than a reflection on history. Indeed, "I felt like a man with an inefficient torch stumbling through a labyrinth" (1993: 278), says Muir in his "Afterthoughts to an Autobiography". This is also one of the many instances of the poet's interest in Greek myth, such as "Oedipus", "The Other Oedipus", "Prometheus", "The Grave of Prometheus", and "Orpheus' Dream". As we read on to the end of the poem, we learn that the world outside the labyrinth is also problematic, and its intricacies embarrass the poet as much as the labyrinth did. In fact the labyrinth, as Brian Keble (1973: 644) has shown, is one of the most recurrent symbols in Muir's poetry ${ }^{1}$. The poet's conclusion, in a rather platonic twist, is that he will never escape from "the lie, / The maze, the wild-wood waste of falsehood, roads / That run and run and never reach an end, / Embowered in error - I'd be prisoned there / But that my soul has birdwings to fly free" (Muir, 1984: 165). The allegory may be read as an interpretation of the hardships and the grim atmosphere in Glasgow, but also as a pattern of the life of the average modern man: the realization that obscurity and complexity always remain as long as you live.

In reading this passage it soon becomes clear that its language not only says what it says, it is actually enacting it: the syntax is "deliberately labyrinthine, to give the mood" (MacCullough, 2014: 74). The whole of these thirty lines consists of one single sentence, which is not only amazingly long but also packed with parentheses and subordinate clauses. The period moves forward like a winding road where you can never see the end: the predicate of the main sentence is constantly eluded or deferred. This strange grammar adds a degree of difficulty to the reader's progress; he is forced to stumble through a maze of signs in the same way the hero of the poem does ${ }^{2}$. So again meaning and form — not stanzaic form in this case as in "The Return of the Greeks", but blank verse and long period - are very closely bound together, and this is due to an exercise of intertextuality that avoids the obvious reference (there is only one oblique and brief allusion to the episode of the Minotaur in the first few lines). 
"The Labyrinth" evinces a second element of intertextuality that should be noted: Kafka. It was Muir and his wife Willa who translated works such as The Trial. In fact, Muir took his sonnet "To Franz Kafka" as the portico to Part II of One Foot in Eden (1956): according to him, the Czech writer could "read on all the leaves of sin / eternity's secret script" (1984: 233 ), in a somewhat optimistic interpretation of Kafka's gloomy universe.

Elgin W. Mellown (1964b: 315) argued that Muir's awareness of the individual's difficulty in finding a place in the disintegrating society of modern civilization urged him to recognize the same angst in Kafka (especially in Das Schloss, one of his first translations from Kafka, and in the drama of K., the foreigner who cannot settle anywhere). I think this is true, but the optimistic twist in the final lines of "The Labyrinth" shows also Muir's religious reading of Kafka, which took place during the debate between those who supported that theological view, such as Hans-Joachim Schoeps or Max Brod, and those who viewed Kafka as a political writer, such as Benjamin and Arendt ${ }^{12}$. At first, in his "Introductory Notes" to The Castle, Muir compared Kafka's writing to Bunyan's allegories in The Pilgrim's Progress, but later in his Essays on Literature and Society he stressed the differences rather than the similarities and argued that Kafka's allegories were not part of a consistent or orthodox theological system but "serious fantasies". Anyway, what should be stressed here is that his "religious" interpretation of Kafka shares the same roots as his turning towards myth: a search for meaning beyond fact (according to J. Brooks Bouson (1979: 30), oppression was for Muir merely "the logical extension of the modern worldview which denies (...) the spiritual significance of life", and that is precisely what both religion and myth provided). The main topic in Kafka's stories, according to Muir, was then human life "whenever it is touched by (...) divine law and divine grace" (1930: vii). That was the only possible chance of an exit from the labyrinth.

The whole meaning of this poem - that the maze of life is a path and the path is in turn a maze, but the poet nevertheless can have a glimpse of an outer or transcendent reality - might be described therefore as "Kafkaesque" and could be linked with Kafka's struggle for sense ${ }^{3}$; in his own essay on Kafka, as Travis L. Livingston (1977: 44) has shown, Muir himself suggested this "optimistic" reading of Kafka's work and underlined the centrality of the symbol of the road in it, and therefore the idea that in spite of all the confusions in which Kafka was involved "he held that the right way exists". One does not need to go too far to guess that, while writing about Kafka, Muir was somehow analyzing himself. In fact, it was this personal characteristic that Spender underlined in his portrayal of Muir, in World within World (1951): unlike himself, rather a "wanderer", Muir had managed to turn a life of shifting jobs "into a spiritual pilgrimage" (1951: 290). He had come to accept the labyrinth and found meaning there.

As a result, the metaphor of the maze and that of the road are intertwined here. Thus, "The Labyrinth" recycles Kafka's motif of the ironic impossibility of the hero to get to his destination, as in "Before the Law", The Castle, "A Message from the Palace" and other stories; 
it was a central motif in Kafka's work, "the obsessive search into the ramifications of an object", in Spender's words (1951: 290). So what we have here is a poet not only writing with a highbrow view of European culture in his mind (with Greek myth as its chief reference) but also with an emblematic modernist influence (Kafka), with whom he was so well acquainted. This is not the work of a mere craftsman or a ballad writer.

The third example comes from The Narrow Place (1943): "The Ring". It is —along with "Mary Stuart", "Robert the Bruce", "The Incarnate One" or "Scotland's Winter"- one of those pieces in which Muir mused on the history of his native land. His Autobiography includes recurring memories on Scotland, and religion is often a major concern: first, we get an idyllic picture of the Orkneys, free of "the torments of ambition" and of "competition", where people lived "an order, and a good order", wherefrom the poet plunged into "chaos" when his family moved to Glasgow; then, a gentle satire of religious conversion worked by wandering preachers common in those days in the Orkneys; later, a recognition of "the quality of Scottish Calvinism" and its "unanswerable, arbitrary logic of predestination" in a few anecdotes. The verdict is unanimous: a world of courage and honor lying in a heroic past and represented by Robert the Bruce and William Wallace, or a world of harmony and balance envisaged in an agrarian Scotland, stand in marked contrast to the present world of decay:

Long since we were a family, a people,

The legends say; an old kind-hearted king

Was our foster father, and our life a fable.

Nature in wrath broke through the grassy ring

Where all our gathered treasures lay in sleep -

Many a rich and many a childish thing.

She filled with hoofs and horns the quiet deep.

Her herds beat down the turf and nosed the shrine

In bestial wonder, bull and adder and ape,

Lion and fox, all dressed by fancy fine

In human flesh, and armed with arrows and spears;

But on the brow of each a secret sign

That haughtily put aside the sorrowful years

Or struck them down in stationary rage;

Yet they had tears that were not like our tears,

And new, all new, for Nature knows no age.

(C) Servicio de Publicaciones. Universidad de Murcia. All rights reserved. IJES, vol. 21(2), 2021, pp. 83-100

Print ISSN: 1578-7044; Online ISSN: 1989-6131 
Fatherless, sonless, homeless haunters, they

Had never known the vow and the pilgrimage,

Poured from one fount into the faithless day.

We are their sons, but long ago we heard

Our fathers or our fathers' fathers say

Out of their dream the long-forgotten word

That rounded again the ring where sleeping lay

Our treasures, still unrusted and unmarred. [Muir, 1984: 113]

The sense of loss, as in Muir's poems about the Eden myth, is obvious. Who is to blame? Muir provides a rather controversial response: the Reformation. "Knox and Melville clapped their preaching palms / and bundled all the harvesters away" (1985: 97), we read in "Scotland 1941". "How could our race betray / the Image?", the poet also asks in "The Incarnate One", the answer being it was the fault of "Calvin's kirk" (1984: 228). In fact, Muir had a profound knowledge of this: he wrote a biography of Knox and he later declared that "I came to dislike him more and more", so much so that the main fault of his book was "it was too full of dislike for Knox" (1993: 226). According to him, then, it was severe Calvinistic religious zeal that deprived the Scottish spirit of the more sensitive element he recognized in the Italian Renaissance during his days in Rome. Such an element was crucial to Christianity insofar as the core of its dogma is Incarnation, the belief that God has lived in human flesh. In fact, as he stated in Scott and Scotland (1936), in Muir's interpretation both the Reformation and the Industrial Revolution went together, in what reads as a narrative of the caesura that points again to a paradisiacal depiction of pre-Reformation Scotland.

This does not mean that Muir sought to become a Catholic. True, as he confessed in his Autobiography, for many years he had believed in God and the immortality of the soul, until in 1939 he came to realize one day that "quite without knowing it, I was a Christian" (1993: 242), but he never joined any particular confession and he could be considered as belonging one step beyond the world that Kolakowski described in Religious Consciousness and Church Affiliation (1965). What it does mean is that, as early as 1922, when he wrote "North and South", he read in European culture from the Renaissance onwards a "longing for the South" as for a home from which men were "exiled", which is easy to recognize in Winckelmann, Goethe, Burckhardt, Nietzsche, or in Keats, Shelley, and Browning. Above all, it means that Muir supported the idea that due to Knox's Reformation and his translation of the Holy Scripture, the Geneva Bible, a "dissociation" had taken place within the Scottish soul: on the one hand, English had become the language of the kirk, of reason and literacy, while on the other hand, 
Scots retained the language of sentimentality ${ }^{4}$. Now what could be closer to Eliot's idea of "dissociation of sensibility", i.e. the notion that in the days of Donne thought and sensation went together but have been split apart in modern culture ${ }^{5}$ ? And, on the other hand, what argument could fit best Muir's narrative of the fall and of a lost preindustrial paradise, as he retold it in his notebooks: "I was born before the Industrial Revolution. [...] Then in 1751 I set out from Orkney for Glasgow. When I arrived, I found I was not in 1751, but 1901" (1993: $289)^{6}$ ?

So "The Ring" is a poem about a unity that has been lost and needs to be restored, in a sense not too distant from his friend's notion. The very title and the first line suggest so: a ring, a circle, is the image of perfection, of fullness and integrity, and therefore of some sort of timeless self-sufficiency that has been disrupted by "wrath", which is to say, by history as conflict (and not "fable" as on the third line, anymore, "fable" meaning merely "myth" in Muir's personal lexicon). But it is not only unity within the individual that has been lost: national unity, due to religious wars (the "family", the "people" in the first line, that reads almost like an echo of the first line in "Scotland 1941") and cultural unity are likewise lost. How does the poem attempt to restore that unity? The answer lies again in form and intertextuality: "The Ring" is written in terza rima and evinces a gnomic use of animals: adder, ape, lion, fox. Both aspects point to one and the same source: Dante.

This is not the only place in Muir's work where his reading of Dante can be traced; there is also terza rima in the sixth piece of "The Journey Back" and "Head and Heart", and the vision of Paolo and Francesca in "The Dreamt-of Place", for instance. In his Autobiography (1993: 143), he remembered the days when he began to read Dante and used some passages as a pattern to understand his own experience, so Margery Palmer MacCulloch (2015: 209) was somehow right when she wrote that Muir "moved away from the Elizabethans, towards Dante": for him, the poet of the Commedia represented part of the world he encountered in Rome, a world that constantly reminded him through its magnificent art that "Christ was born in the flesh and had lived on the earth" and where Gabriel and Mary "gazed upon each other like Dante's pair" (1993: 274); somehow, he wrote, he became aware that he shared with the Tuscan poet "some archetypal image in our minds", of which we only become aware "when we realize that our own life is a journey" (1993: 212). If his own existence was a pilgrimage, so was Dante's narrative.

I think Eliot's influence and friendship shows here. This is not to say that Eliot was the only English modern poet to try terza rima (Shelley, for instance, had done so in The Triumph of Life, in a mood that sounds much closer to Dante's) or even the only one to admire Dante (the list should include Blake, Coleridge, Dante Gabriel Rossetti, Pound, and Auden). But there is indeed a coincidence that should be stressed: Eliot wrote his Little Gidding in 1941 and Muir might even have had the privilege of reading the manuscript before the poem was published in 
1942 (at the same time, Eliot used several quotations from Dante's Inferno already in "The Burial of the Dead", the first part of The Waste Land, in 1922). And Muir's The Narrow Place, which includes “The Ring”, was published in 1943. Besides, we know from his letters to Conrad Aitken and David Peat that Muir was reading Dante in the early forties.

This could account for the vision of Dante underlying "The Ring": against that world of "dissociation", Dante would represent a quest for unity, not only because of the sense of wholeness in the Commedia and the fact that Dante's Christianity was "European" Christianity before schism came, but also because his whole intellectual achievement, especially $D e$ monarchia and De vulgari eloquentia, evidence a longing for the unity of the Empire and an attempt to build a new one (religious, political and linguistic); if there was one poet who could serve as a weapon to counteract division and Protestantism, that was Dante. Or maybe Eliot's Dante, the one we find in "What Dante Means to Me": a homage in the hands of an (AngloCatholic writer who praises the author of the Commedia because there has never been a poet that is "so universal without ceasing to be local" (1991: 135). It is no surprise then to find that in the 1921 essay on metaphysical poets the first name on the list of those who wrote before the "dissociation of sensibility" was Dante. His sense of inclusiveness, in an all-encompassing achievement, was unique ${ }^{7}$.

This means that writing after Dante, as Muir does, was a challenge. Eliot himself confessed in his 1950 talk that the terza rima section of Little Gidding cost him far more trouble than any other passage that he had ever written, not only because of the Dantesque type of imagery, but also because of "its bare and austere style, in which every word has to be 'functional', the slightest vagueness or imprecision is immediately noticeable" (1991: 129). And this sense of challenge, an anxiety of influence avant la lettre, has to do both with Muir's private concerns (his late literary vocation and his slow search for recognition) and with the whole literary strategy in the Commedia, where Dante uses Virgil as his duca, and yet manages to move beyond him (inasmuch as Virgil, a heathen, cannot enter the Paradiso). The picture looks like a staircase: Eliot and Muir are using Dante, who in turn used Virgil as a guide, and in admitting their debt they also somehow claim their birthright. Eliot was quite conscious of the self-encumbering game he was playing in joining that tradition, and Muir seems to be glad to take part in it.

Summarizing, in his Autobiography Muir lamented the fact that he had come to read Dante so late and suggested his view of the Tuscan poet was quite close to Eliot's. "I know now", he wrote (1993: 201), "what Eliot means when he says that Dante is the best model for a contemporary poet". Moreover, while in Italy he still recognized in everyday speech "something of the accent of Dante, who spoke more directly from the heart than any other poet" (1993). In a word, Muir's Dante was a poet, maybe the poet of what Coleridge would call "esemplastic power"; he lived in a world of flesh and blood before Eliot's "dissociation", and 
he epitomized the "unity" - Catholicity, rather than Catholicism — whose loss is mourned in "The Ring". So again we find a broader poetic horizon than the narrow world of ballads: instead, we find a view of European culture and a rereading of a classical author via a modernist interpretation; and the whole process is worked out through form and intertextuality - in fact, form becomes here an act of intertextuality.

The fourth and final example is a twofold one: "Moses" (The Voyage, 1946) and "Abraham" (One Foot in Eden, 1956), part of a series based on biblical episodes, such as “Adam's Dream", “Outside Eden", “The Succession”, “The Killing”, and "One Foot in Eden". The first may be read as a dramatic monologue and, therefore, as a discourse not untypical of modernism (Eliot's idea of dramatic monologue can be ascertained in his essay "The Three Voices of Poetry", 1954). The character in "Moses" sounds like a spokesman, speaking in the first person plural as a representative of the whole of Israel; he describes Moses gazing on Canaan, satisfied that he has managed to take his people to the promised land, only

\author{
Moses did not see \\ The great disaster exile, diaspora, \\ The holy bread of the land crumbled and broken \\ In Babylon, Caesarea, Alexandria \\ As on a splendid dish, or gnawed as offal. \\ Nor did we see, beyond, the ghetto rising, \\ Toledo, Cracow, Vienna, Budapesth, \\ Nor had we seen, would we have known our people \\ In the wild disguises of fantastic time, \\ Packed in dense cities, wandering countless roads, \\ And not a road in the world to lead them home. \\ How could we have seen such things? [Muir, 1984: 130]
}

It should be remembered that "Moses" was published in 1946, that is, in the aftermath of World War II, right after the Shoah; that it was written by a British citizen while the UK ruled over Palestine; and that this British citizen was then living in Prague, so he was constantly hearing stories about the Nazi Occupation, but he also had to the still impending spirit of antiSemitism, as we read in his Autobiography (1993: 209-210). The line "Toledo, Cracow, Vienna, Budapesth" may encapsulate the meaning of the poem: Toledo, where Jews had been tolerated until 1492; Cracow, just a few miles from Auschwitz, in the area then known as "the European Jerusalem"; Vienna and Budapest, both capitals of the extinct Habsburg Empire, where the Jews had been cruelly massacred. The conclusion is obvious: anti-Semitism is certainly old, but it has worsened; and the only way for a Jew to feel safe is to secure a Jewish State. In the 1946 
context, this reads as a declaration supportive of Zionism as an inevitable consequence of the Holocaust. It was when the Jews left Canaan, when they let that land be "trampled by sequent tribes, seized and forgotten", that they were forced to live in ghettoes. And it was Britain's duty to grant them their right to have their own land. Ten years later, "Abraham" sounds quite different:

The rivulet-loving wanderer Abraham

Through waterless wastes tracing his fields of pasture

Led his Chaldean herds and fattening flocks

With the meandering art of wavering water

That seeks and finds, yet does not know its way.

He came, rested and prospered, and went on,

Scattering behind him little pastoral kingdoms,

And over each one its own particular sky through which he journeyed,

That went with him but when he rested changed.

His mind was full of names

Learned from strange peoples speaking alien tongues,

And all that was theirs one day he would inherit.

He died content and full of years, though still

The Promise had not come, and left his bones,

Far from his father's house, in alien Canaan. [Muir, 1984: 221]

"Abraham" is one among those pieces that show Muir's familiarity with the Bible (which was read every Sunday evening at home when he was a child); but, like many modern poems that take episodes from the Bible and subvert them in order to criticize recent history think, for instance, of Wilfred Owen's "Parable of the Young Man and the Old" - it is also a piece of irony: the promised land has proved a disappointment; it is, in fact, a place of alienation. We can say, then, there is a dialogue between "Abraham" and "Moses", the former acting as a palinode to the latter. Why? Because after Muir wrote his "Moses" a civil war came early in 1948; then in May, after the foundation of the State of Israel, members of the Arab League refused to accept the UN partition plan and started the first Arab-Israeli war; and in 1956, the very year when "Abraham" was published, the Suez Crisis broke out; those ten years were a series of battles, truces and unrecognized borders. Israel was being hard on Palestinians, Zionism might not be such a good idea after all.

The argument in "Abraham", thus, suggests an unorthodox position: that of cultural Zionism, the idea that —unlike Theodor Herzl's political Zionism, whose goal was the 
foundation of a Jewish State - what European Jews needed was to be allowed to live as Jews, they did not need to move to Israel. Its best-known leader was Martin Buber (1978-1965), who demanded an overall spiritual renewal rather than a merely national one. And where did Buber come as a revelation to young Central European Jews? In the same Prague where Muir worked for the British Council after the war, in the speeches Buber gave for the Bar Kochba association in Prague, from 1909 to the early twenties, and members included Hugo Bergmann and Max Brod, both friends of Kafka's (the writer was not very impressed by Buber at first, as Iris Bruce (2007) has shown, but after 1917 he was very interested and sent some short stories to Der Jude, Buber's review).

So the events in the fifties must have brought to the poet's mind the idea that things need not always remain in their current forms: according to some cultural Zionists —or even nonZionist Jewish writers, such as Joseph Roth in The Wandering Jews (1928) - diaspora was not a damnation but a blessing, because it meant a Jew could dwell anywhere, and his settling was a germ of civilization. This is also one possible interpretation of The Castle, Kafka's novel, which Edwin and Willa translated (revealingly, under the guidance of Max Brod, who was converted to Zionism by Buber's speeches). And this is exactly what we find in "Abraham", where the patriarch "came, rested and prospered, and went on, / scattering behind him little pastoral kingdoms", where his mind was "full of names / learned from strange peoples" and all that was theirs "one day he would inherit" (1984: 221). Not having a native land of your own meant that you could live anywhere, the Jewish people was not a nation but a supra-nation; and the State of Israel had betrayed that perspective, in the poet's view. Muir, who must have been acquainted with this unorthodox branch of Zionism during his first sojourn in Prague, when the echo of Buber's speeches could still be heard, only had to remember that. Again, the irony in "Abraham" and its dialogue with "Moses" shows a deep interest in history, that of a cosmopolitan poet who is concerned with contemporary issues, not a ballad writer secluded in some cultural backwater. 


\section{TRADITION, PERMANENCE, CREATIVITY}

As a conclusion, it may be said that Muir has been misunderstood for some time. In fact, the poet himself caused that misunderstanding when he wrote that at first he took to ballad writing because he "lacked technique" or that as a child he had no poetry books but knew ballads and songs "which had been handed down from generation to generation" (1962: 9). However, the fixed idea of tradition underlying that perspective, the idea of a tradition that, unlike Eliot's definition in "Tradition and individual Talent" (1917), need not be earned, does not do any justice to the later Muir, who, as we have seen, viewed tradition as something he could adhere to certainly, but also as something he could add and innovate within or upon (in Transition: Essays in Contemporary Literature he also criticized Eliot's idea of tradition as slightly tyrannical).

Is Muir then a craftsman, not an artist? In fact, this is the claim that he himself saw as Pound's main shortcoming: that he was a mere craftsman in an age that demanded that the poet should build "a conception of life". Is he just "traditional", not "modern"? If we accept Malcolm Bradbury and James MacFarland's idea of the "Great Divide" provoked by modernism (1976: 19-26), classical form cannot simply be read as a relic after modernism and the avant-garde, while, on the other hand, seeing experimentalism as a self-evident sign of sophistication might be misleading. Does that turn Muir into a "contemporary", in Spender's terms? No, because the contemporary, although he belongs to the modern world, cannot see "modern life as a whole" (1963: 77). My view is that Muir's work reflects that whole, and there are several aspects that support this line of argument.

First, nothing suits best the core of the modern sequence (industrial revolution, rural exodus, urban alienation, search for meaning) than Muir's own experience and the narrative pattern he insisted on throughout his career, both in his poetry and in his autobiography: nostalgia for a Scotland that had vanished plus rewriting of the Eden myth. Secondly, Muir was aware of the existence of a Zeitgeist; only, as he wrote in the first pages of Transition (1976: 422), simply belonging to one's time does not mean a poet must be subservient to it; in fact, in Antoine Compagnon's logics, as shown in Les antimodernes (2005), fighting modernity could be one way of being modern (not only did Muir never turn his back on contemporary life, he was the first poet to write about the threat of nuclear war in "After a Hypothetical War", for instance). Thirdly, it should be remembered that Muir's very first book was titled We Moderns and that, although he later rejected its post-Nietzschean attitudes, many of the concerns he reflected on there persisted during his Christian phase ${ }^{8}$ the questions were the same, only the answers changed (by the way, his rejection of realism as decay and his attitude towards authors such as Pater and Wilde fit Edmund Wilson's idea of modernism as continuity with nineteenthcentury symbolism in Axel's Castle, which would characterize Muir as a "mild modern"). 
Fourthly, this rejection of realism and its limitations shows in one aspect that is constant in Muir's poetry, his use of myth; already in We Moderns he wrote that "against aimless realism we must oppose idealization and especially that which is its highest expression, myth" (1918: 143); and this was just four years before Eliot proposed his "mythic method" as a way of "controlling, of ordering, of giving a shape and a significance to the immense panorama of futility and anarchy which is contemporary history" (1923: 483). On the other hand, W. S. di Piero's interpretation (1990: 83), that Muir took to myth because it survives due to its essentially "static, unchanging", nature, as it lies "beyond fact", can account both for the timelessness and the universality he was searching for: his use of myth has a lot to do with psychoanalysis and Jungian ideas about archetype, the notion that every man enacts "the life of man", the "fable", and therefore myth can bridge the gap between individual and collective experience (also, as we read in The Estate of Poetry (1962: 28-30), with a nostalgia for narrative poetry as vindicated by Matthew Arnold in his Empedocles and now only written by just a few poets, like Frost or Eliot $)^{9}$.

Finally, it must be said that, despite the parallels between some of their ideas, Muir was not uncritical of Eliot's work (his voice seemed to him too "reluctant" or "inconclusive", he wrote in Transition) or Pound (in "The Present Age from 1914", 1939, he envisaged Pound as the archetypal poet who rises to greatness in an age of faith, when men's conception of life is given to them "complete, objectively", and all the poet has to do is "say it out", but that was not the case in modern times). Muir then would be one of those who searched for "permanent values" in the midst of modern cataclysm (and therefore the afore mentioned "timelessness": in We Moderns he blamed most "modern" authors for living only in the present and ignoring the past, and certainly myth is a way to avoid such a precarious situation) and who shared Hulme, Eliot and Auden's idea of man as a fallen creature in need of some redemptive force (his concern with original sin may be traced already in the first chapters of We Moderns and is one of the reasons for his obsession with the theme of Eden). Despite the sound and fury of the avant-garde, Muir claimed then that "poetry will not be truly contemporary if it deals merely with the immediately perceived world as if that existed by itself and were isolated from all that preceded it" (1962: 92). He was certainly a latecomer, and he had not been there in the first years of modernism, when Hulme preached his new creed and Eliot overwhelmed the Georgian reader with his Prufrock, but he could be placed among those who after 1925 followed Cocteau's rappel à l'ordre or who, like Eliot, deemed themselves "classical". In fact, his understanding of the phenomenon was that there was an excuse for those years of experiment around 1910 because English poetry, in the hands of Edwardian poets, had come to a dead end and it was impossible to breathe any new life into the tradition of Wordsworth. He just had skipped that phase. 


\section{NOTES}

${ }^{1}$ According to Catherine Tzuganatov (1955), it features in eight of Muir's poems.

${ }^{2}$ In Harvey Gross and Robert MacDowell's words, if it is always the rhythm of the poem that gives time a meaning and a form, the syntax of "The Labyrinth" "acts out the journey of Theseus" (1968: 64).

${ }^{3}$ Margery Palmer MacCullough (2014: 74) claims the whole of Muir's poetry is "potentially kafkaesque" in that it explores "the double-natured condition of human life and experience and its redemptive search for something that has been lost". Ritchie Robertson (1984: 65) added that one of the traits of Kafka's writing that seized Muir's attention was the "eternal present" in Das Schloss, which seemed to abolish historical time and therefore approached the "timelessness" of myth.

${ }^{4}$ This is why, as Douglas Gifford (2007: 340) has pointed out, in Muir's view, instead of a "Reformation" Knox's legacy would lead to a "Deformation" of the Scottish mind; that would account for Muir's idea of a Scottish Renaissance that should go back to the $16^{\text {th }}$ century and take writers such as William Dunbar, instead of Burns or Scott, as their model.

${ }^{5}$ In Eliot's view, one of the chief characteristics of Donne and Herbert's writing was their "telescoping of images and multiplied associations" (my italics), because these poets possessed "a mechanism of sensibility which could devour any kind of experience" (Eliot, 1951: 287); and that is precisely what was lost, and the reason why Tennyson and Browning "cannot feel their thought as immediately as the odour of a rose".

${ }^{6}$ In his first book, We Moderns (1918), Muir developed an unorthodox Christian pet theory of original sin that would equate it with "intellectualism" and Nietzschean "war on the instincts" (1920: 46).

7 "What Dante Means to Me" was published in 1950, long after Muir's poem, but Eliot's admiration for the Italian poet was no secret among friends like Aitken, Pound or Muir himself.

${ }^{8}$ In his Autobiography Muir recalled his indebtedness to Orage, editor of The New Age, and the years when Nietzsche was a "drastic stimulus" who "intoxicated me with a feeling of false power" (1993: 118); he also explained his clinging to Nietzsche's philosophy as guided by the logics of "compensation"; he even had a dream in which the German philosopher was crucified.

${ }^{9}$ See J. E. Gilmer's study The Archetypal Fable (1969: 13-19).

\section{REFERENCES}

Bold, A. (1976). Notes to Poems. In A. Bold (Ed.), Cambridge Book of English Verse 1939-1975 (pp. 170-249). Cambridge: Cambridge University Press.

Bouson, J. B. (1978). Journeys and Places: A Study of the Poetry of Edwin Muir. Chicago: Master's Theses, Loyola University, United States.

Bouson, J. B. (1979). The Survival of the Human Spirit in an Age of Crisis: Edwin Muir's View of Modern History. Cithara, 19(1), 26-39.

Bradbury, M. \& James M. (1976). The Name and Nature of Modernism. In M. Bradbury \& J. McFarlane (Eds.), Modernism (pp. 19-56). Harmondsworth: Penguin.

Bruce, I. (2007). Kafka and Cultural Zionism. Madison: The University of Wisconsin Press.

Butter, P. H. (1966). Edwin Muir: Man and Poet. London: Oliver \& Boyd.

(C) Servicio de Publicaciones. Universidad de Murcia. All rights reserved. IJES, vol. 21(2), 2021, pp. 83-100

Print ISSN: 1578-7044; Online ISSN: 1989-6131 
Compagnon, A. (2005). Les antimodernes. Paris: Gallimard.

Dickney, J. (2004). Classes on Modern Poets and the Art of Poetry. (Donald J. Greiner, Ed.) Columbia: University of South Carolina Press.

Di Piero, W. S. (1990). On Edwin Muir. Chicago Review, 37(1), 80-88.

Edwin Muir. (n.d.). Retrieved June 28, 2020 from https://en.wikipedia.org/wiki/Edwin_Muir

Eliot, T. S. (1923). Ulysses, Order, and Myth. The Dial, 75(5), 480-83.

Eliot, T. S. (1936). Selected Poems 1909-1935. London: Faber \& Faber.

Eliot, T. S. (1951). The Metaphysical Poets. In Selected Essays (3rd ed.). (281-291). London: Faber \& Faber.

Eliot, T. S. (1953). Tradition and the Individual Talent. In Selected Prose (21-30). Harmondsworth: Penguin.

Eliot, T. S. (1957). The Three Voices of Poetry (pp. 89-102). In On Poetry and Poets. London: Faber \& Faber.

Eliot, T. S. (1991). What Dante Means to Me. In To Criticize the Critic (125-135). Lincoln: The University of Nebraska Press.

Frisardi, A. (2000). The Anomaly of Edwin Muir. The Hudson Review, 52(4), 576-586.

Gifford, D. (2007). Sham Bards of a Sham Nation?: Edwin Muir and the Failures of Scottish Literature. Studies in Scottish Literature, 35(1), 339-361.

Gillmer, J. E. (1969). The Archetypal Fable: An Inquiry Into the Function of Traditional Symbolism in the Poetry of Edwin Muir. Grahamstown: Thesis at Rhodes University, South Africa.

Gross, H. \& Robert M. (1968). Sound and Form in Modern Poetry. ( $2^{\text {nd }}$ ed.). Ann Arbor: The University of Michigan Press.

Huberman, E. (1971). The Poetry of Edwin Muir. New York: Oxford University Press.

Keeble, B. (1973). In Time's Despite: On the Poetry of Edwin Muir. The Sewanee Review, 81(3), 633658.

Kolakowski, L. (1969). Chrétiens sans Église: la conscience réligieuse et le lien confessionel au XVIIème siècle. Paris: Gallimard.

Livingston, T. L. (1977). The Symbolic Use of Greek Myth and Biblical Saga in the Poetry of Edwin Muir. Electronic Theses and Dissertations, Graduate Faculty of Texas Tech University, United States.

Luhrs, M. (1925). Piety and Peace: First Poems, by Edwin Muir. Poetry, 27(1), 50-51.

McCullough, M. P. (2014). European Influences: Edwin Muir, Kafka, and the Spirit of Italy. Complutense Journal of English Studies, 22, 69-80.

McCullough, M. P. (2015). The Waste Land Was Made Out Of Splinters: T. S. Eliot, Edwin Muir and Contrasting Influences. T. S. Eliot, France, and the Mind of Europe, ed. Jayme Stayer. Newcastle upon Tyne: Cambridge Scholars Publishing, 204-213.

Mellown, E. W. (1964). Bibliography of the Writings of Edwin Muir. Tuscaloosa: University of Alabama Press.

Mellown, E. W. (1964). The Development of a Criticism: Edwin Muir and Kafka. Comparative Literature, 16(4), 310-321.

Muir, E. (1920). We Moderns. New York: Alfred A. Knopf.

Muir, E. (1930). Introductory Notes. The Castle. London: Martin Secker, vi-xii.

O) Servicio de Publicaciones. Universidad de Murcia. All rights reserved. IJES, vol. 21(2), 2021, pp. 83-100

Print ISSN: 1578-7044; Online ISSN: 1989-6131 
Muir, E. (1962). The Estate of Poetry. London: Hogarth Press.

Muir, E. (1976). Transition: Essays on Modern Poetry. New York: The Viking Press.

Muir, E. (1984). Collected Poems. London: Faber \& Faber.

Muir, E. (1993). Autobiography. London: Canongate Press.

Raine, K. (1964). Edwin Muir: An Appreciation. Texas Quarterly, 4, 233-245.

Richman, R. (2020). Edwin Muir's Journey. The New Criterion, 38(8). Retrieved September 18, 2021 from https://newcriterion.com/issues/1997/4/edwin-muirs-journey

Robertson, R. (1984). Edwin Muir as Critic of Kafka. The Modern Language Review, 79(3), 638-652.

Shaw, R. B. (2007). Blank Verse: A Guide to Its History and Use. Athens: Ohio University Press.

Spender, S. (1951). World within a World. London: Hamish Hamilton.

Spender, S. (1963). The Struggle of the Modern. London: Hamish Hamilton.

Summers, J. H. (1976). The Achievement of Edwin Muir. The Massachusetts Review, 2(2), 240-260.

Tzouganatov, C. (1955). Labyrinth of Edwin Muir (Master of Arts Thesis). Retrieved from Graduate Student Theses, Dissertations, \& Professional Papers. (2802). Scholar Works at the University of Montana, United States.

Wilson, E. (2004). Axel's Castle. New York: Farrar, Straus and Giroux. 